\title{
Phytochemical composition, antibacterial and modulatory of antibiotic activity of the extract and fractions from Annona squamosa $\mathrm{L}$.
}

Heloisa H.F. Souza ${ }^{1}$, Cícera N. Fernandes ${ }^{1}$, Saulo R. Tintino ${ }^{2}$, Maria Flaviana B. Morais-Braga ${ }^{2}$, Antonia C. Araújo ${ }^{1}$, Henrique D.M. Coutinho $^{2^{*}}$, Irwin R.A. Menezes ${ }^{1}$ and Marta R. Kerntopf ${ }^{1}$

\footnotetext{
${ }^{1}$ Laboratório de Farmacologia e Química Molecular - LFQM, Departamento de Química Biológica, Universidade Regional do Cariri - URCA, Rua Cel. Antonio Luis 1161, Pimenta, 63105-000, Crato-CE, Brasil. Fone: +55(88)31021212; Fax +55(88) 31021291.

${ }^{2}$ Laboratório de Microbiologia e Biologia Molecular - LMBM, Departamento de Química Biológica, Universidade Regional do Cariri - URCA, Rua Cel. Antonio Luis 1161, Pimenta, 63105-000, Crato-CE, Brasil. Fone: +55(88)31021212; Fax +55(88) 31021291.

* Corresponding author:

$\triangle$ E-mail adresses: HDMC (hdmcoutinho@gmail.com)
}

Ethnobiology and Conservation, 2: 9 (22 October 2013)

ISSN 2238-4782

doi: 10.15451/ec2013-8-2.9-1-08

ethnobioconservation.com

\section{Abstract}

The medicinal plants and natural products are products with a great scientific interest due their possible use like phytodrugs. In this context, the phytochemical composition and the antibacterial and antibiotic modulatory activity of the extract and fractions of Annona squamosa against Staphylococus aureus and Escherichia coli were performed. All natural products have not showed clinically relevant antibacterial activity, with MIC $\geq 1024 \mathrm{mg} / \mathrm{mL}$. However, the extract combined with some aminoglycoside showed a synergistic effect against multiresistant strains E. coli 27 and S. aureus 358. Due these results, $A$. squamosa (Annonaceae) must be more studied to be used as a source of natural products with adjuvant potential to enhance the antibiotic activity, combating by this way the microbial antibiotic resistance.

Keywords: Antibacterial activity - Escherichia coli - Modulator activity Staphylococus aureus 


\section{Introduction}

The indiscriminate use of antibiotics has increased of the microbial resistance to these drugs, indicating the necessity of the research for new antibiotics. The study of the bacterial resistance is often based in microorganism with epidemiological importance and responsible for different infectious process (Moellering 2000). In the search of new therapeutic alternatives, natural products and remedies has been the target of a great scientific interest due their pharmacological activities and chemical characteristics to be used as drugs (Michelin et al. 2005; Lima et al. 2006).

Annona squamosa L. (Annonaceae) is known popularly like "pinha", "ata" or "fruta-do-conde". In Brazil, there are almost 250 species of the family Annonaceae (Souza and Lorenzi 2008). This plant is native from Central America and is cultivated in the northeastern region of Brazil due its value as a food "in natura" (Souza and Lorenzi 2008). In the traditional medicine, parts of this plant are used as insecticide, antispasmodic, antidiarrheal, analgesic and anti-inflammatory (Vohora et al. 1975; Womg et al. 1993; Brito et al. 2008; Roig 1988; Robineau 1995; Amador et al. 2006).

Due this importance, the aim of this work has was analyze perform the phytochemical prospecting and evaluate the antimicrobial and modulatory antibiotic activity of the ethanol extract Annona squamosa (EEAS) and hexane (HFAS), ethyl acetate (EAFAS) and methanolic (MFAS) fractions against the multiresistent strains of Staphylococus aureus and Escherichia coli.

\section{Material and Methods}

\section{Plant Material}

Leaves of ten different individuals of Annona squamosa were collected in the County of Crato, Ceará, Brazil. The plant was identified by Dr. Maria Arlene Pessoa da Silva and deposited at Herbarium Caririense Dárdano de AndradeLima of the Regional University of Cariri - URCA, under number 5539 HCDAL.

Preparation of Ethanol Extract and Fractions of the Annona squamosa $L$. (EEAS)

Fresh leaves of Annona squamosa (275g) were weighted and macerated using the extraction with ethanol for a period 72 hours. The solvent was distillated in a rotary evaporator at $80^{\circ} \mathrm{C}$ under low pressure, obtaining $10.2 \mathrm{~g}$ of the extract. The extract was stored at room temperature using ambar glass. The fractioning protocol used $5 \mathrm{~g}$ of the extract. The extract was mixed with silica and filtered with vacuum using the follow solvents P.A: Hexane (HFAS), ethyl acetate (EAFAS) and methanolic (MFAS).

\section{Phytochemical prospecting}

The phytochemical test to detect the presence of tannins, flavonoids and alkaloids were performed according to the classic method described by Matos (1997). The tests were based on the visual observation of a change in color or formation of precipitate after the addition of specific reagents. 


\section{Drugs}

Gentamicin, Kanamycin, amikacin and neomycin were obtained through Sigma Chemical Co. All drugs were dissolved in sterile water.

\section{Bacterial strains}

The bacteria used in the Minimal Inhibitory Concentration (MIC) test were the standard strains of Escherichia coli ATCC 10536, Staphylococcus aureus ATCC 25923, Pseudomonas aeruginosa ATCC15442 and Klebsiella pneumoniae ATCC 4362. The evaluation of the modulatory activity of the ethanol extract and fractions was assayed against multiresistant bacterial strains isolated of clinical environments: E. coli 27 and S.aureus 358, with the resistance profile demonstrated in Table 1. All strains were obtained through the Laboratory of Clinical Mycology - UFPB.

Table 1. Source of the bacterial strains and resistance profile to antibiotics. Legend: Ast-Aztreonan; Ax- Amoxacillin; Amp-Ampicillin; Ami-Amicilina; Amox-Amoxillin, CaCefadroxil; Cfc-cefaclor; Cf-Cephalothin; Caz-Ceftazinidima; Cip-Ciprofloxacin; CloChloramphenicol; Imi-Imipenem; Can-Kanamycin; Szt-Sulphametrim; Tet-Tetracycline; Tob-Tobramycin; Oxa-Oxacillin; Gen-Gentamicin; Neo- Neomycin; ParaParamomicina; But-Butirosina; Sis-Sisomicin; Net-Netilmicin.

\begin{tabular}{llll}
\hline Bacterium & Origin & Profile of resistance & \\
\hline Escherichia coli 27 & Surgical & Ast, Ax, Ami, Amox, Ca, Cfc, Cf, Caz, Cip, Clo, Imi, Can, \\
& wound & Szt, Tet,Tob \\
Staphhylococcus & $\begin{array}{l}\text { Surgical } \\
\text { wound }\end{array}$ & Oxa, Gen, Tob, Ami, Can, Neo, Para, But, Sis, \\
wet 358 & Net
\end{tabular}

\section{Minimal Inhibitory Concentration}

Broth microdilution was the method used. The substances to be assayed were dissolved using DMSO and diluted to $1024 \mu \mathrm{g} / \mathrm{mL}$ with sterile water. The bacterial inoculum was diluted using $\mathrm{BHI}$ to a final concentration of $10^{5} \mathrm{UFC} / \mathrm{mL}$. A total of $100 \mu \mathrm{L}$ relating to each inoculum was distributed in each well of a microtiter plate with 96 wells, and then submitted to a double serial dilution using $100 \mu \mathrm{L}$ of extract and fractions, with concentrations varying between 512 $8 \mu \mathrm{g} / \mathrm{mL}$. The plates were incubated during 24 hs at $35^{\circ} \mathrm{C}$ (Javadpour et al. 1996). MIC was determined using resazurin. The MIC was defined as the lowest concentration where no growth can be observed according to NCCLS (2003).

\section{Modulatory activity assay}

The determination of the antibiotic modulatory activity of the extract and fractions of $A$. squamosa was realized according the method proposed by Coutinho et al. (2008). The extract and fractions were assayed in sub-inhibitory concentration $(\mathrm{MIC} / 8=128 \mu \mathrm{g} / \mathrm{mL})$. A sample with $100 \mu \mathrm{L}$ of a solution containing $\mathrm{BHI}$, the microbial inoculums and a sub-inhibitory concentration of 
the extract or fractions was placed in each well. $100 \mu \mathrm{L}$ of the antimicrobial drug (f.c. $1024 \mathrm{~g} / \mathrm{mL}$ ) was placed in the first well. This solution was serially two fold diluted, obtaining concentrations ranging between $2500-2.44 \mu \mathrm{g} / \mathrm{mL}$.

\section{Results and Discussion}

The use of natural products like antimicrobial agents show as low risk to increase the microbial resistance due the complex mixtures of these compounds, resulting in a lower adaptative capacity (Daferera et al. 2003; Matias et al. 2010).

The Table 2 shows the presence of many complexes such as condensed tannins, flavones, flavonols, xanthones, chalcones, flavononols, catechins, flavonones and alkaloids, being correlated with the phytocompounds demonstrated by Brito et al (2008). The secondary metabolites identified in the extract of $A$. Squamosa are reported as a source of several biological activities: antimicrobial (Kotkar et al. 2001), antioxidant (Shirwaikar et al. 2004) and antiulcerogenic (Zayachkivska et al. 2005).

Table 2. Phytochemical prospection of the ethanol extract of Annona squamosa L. (EEAS). Legend: 1- Phenols; 2- Pirogalic tannins; 3- Condensed tannins; 4Anthocyanins; 5- Anthocyanidins; 6- Flavones; 7- Flavonols; 8-Xanthones; 9Chalcones; 10- Auronas; 11- Flavononols; 12- Leucoanthocyanidins; 13- Catechins;14Flavonones; 15- Alkaloids; (+) presence; (-) absence.

\begin{tabular}{c|c|c|c|c|c|c|c|c|c|c|c|c|c|c|c}
\hline \multicolumn{10}{c}{ Metabolites } \\
\hline & 1 & 2 & 3 & 4 & 5 & 6 & 7 & 8 & 9 & 10 & 11 & 12 & 13 & 14 & 15 \\
\hline EEAS & + & - & + & - & - & + & + & + & + & + & + & - & + & + & + \\
\hline
\end{tabular}

Phenolic compounds, as tannins and flavonoids, have demonstrated several bioactivities as antiinflammatory, antifungal, antimicrobial, antioxidant, and wound-healing agents (Santos and Mello 2004). Synergism between flavonoids and antibiotics against resistant bacterial strains and the bacteriostatic or bactericidal activity of flavonols have been demonstrated by (Cushnie and Lamb 2005).

The extract and fractions did not presented a clinically relevant antibacterial activity, presenting MIC $\geq 1024 \mu \mathrm{g} / \mathrm{mL}$ (Coutinho et al. 2008). However, the extract and the hexane fraction combined with neomycin showed a synergistic effect against the multiresistant strains of E. coli 27 and S. aureus 358. A synergism was also verified when associated the acetate ethyl fraction with Amikacin and Gentamicin against E. coli 27 (Tables 3 and 4).

Studies done by Kotkar et al. (2001), demonstrated the antimicrobial activity of the flavonoid component of leaves from the $A$. squamosa against strains of Pseudomonas, Bacillus, Cellulomonas and Aspergillus due alterations in the structure of the cell membrane of the assayed microorganisms. These fact is according with the observations of Helander et al. (1998) and Matias et al. (2011). These works reported that many phytoconstituents of this extract can increase the cell membrane permeability, potentiating the effect of antibiotics by an uptake increase. 
Table 3. Modulatory antibiotic activity of natural products of Annona squamosa against E. coli $(\mu \mathrm{g} / \mathrm{mL})$. Legend: EEAS - Ethanol Extract of Annona squamosa; HFAS Hexane Fraction of Annona squamosa; EAFAS - Ethyl-acetate fraction of Annona squamosa; MFAS - Methanol Fraction of Annona squamosa.

\begin{tabular}{c|ccccc}
\hline Antibiotic & \multicolumn{5}{c}{ EC27 } \\
\cline { 2 - 6 } \multicolumn{1}{c}{} & Alone & $\begin{array}{c}+\mathrm{+EEAS} \\
(128 \mu \mathrm{g} / \mathrm{mL})\end{array}$ & $\begin{array}{c}+ \text { +HFAS } \\
(128 \mu \mathrm{g} / \mathrm{mL})\end{array}$ & $\begin{array}{c}\text { +EAFAS } \\
(128 \mu \mathrm{g} / \mathrm{mL})\end{array}$ & $\begin{array}{c}+ \text { +MFAS } \\
(128 \mu \mathrm{g} / \mathrm{mL})\end{array}$ \\
\hline Kanamycin & 1250 & 1250 & 1250 & 1250 & 1250 \\
Neomycin & 312.5 & 39.06 & 312.5 & 312.5 & 312.5 \\
Amikacin & 2500 & 2500 & 2500 & 625 & 2500 \\
Gentamicin & 625 & 625 & 625 & 156.25 & 625 \\
\hline
\end{tabular}

Table 4. Modulatory antibiotic activity of natural products of Annona squamosa against S. aureus $(\mu \mathrm{g} / \mathrm{mL})$. Legend: EEAS - Ethanol Extract of Annona squamosa; HFAS Hexane Fraction of Annona squamosa; EAFAS - Ethyl-acetate fraction of Annona squamosa; MFAS - Methanol Fraction of Annona squamosa.

\begin{tabular}{l|ccccc}
\hline Antibiotic & \multicolumn{5}{c}{ SA358 } \\
\cline { 2 - 6 } \multicolumn{1}{l}{} & Alone & $\begin{array}{c}+\mathrm{EEAS} \\
(128 \mu \mathrm{g} / \mathrm{mL})\end{array}$ & $\begin{array}{c}+\mathrm{HFAS} \\
(128 \mu \mathrm{g} / \mathrm{mL})\end{array}$ & $\begin{array}{c}+\mathrm{EAFAS} \\
(128 \mu \mathrm{g} / \mathrm{mL})\end{array}$ & $\begin{array}{c}+\mathrm{MFAS} \\
(128 \mu \mathrm{g} / \mathrm{mL})\end{array}$ \\
\hline Kanamycin & 39.06 & 39.06 & 39.06 & 39.06 & 39.06 \\
Neomycin & 19.53 & 4.88 & 4.88 & 19.53 & 19.53 \\
Amikacin & 39.06 & 39.06 & 39.06 & 39.06 & 39.06 \\
Gentamicin & 4.88 & 4.88 & 4.88 & 4.88 & 4.88 \\
\hline
\end{tabular}

The combination of natural products with antibiotics can result in a potentiating effect that must be investigated in others plants of Annonaceae family. Leaves of Annona muricata (Annonaceae) demonstrated a synergistic effect associated with aminoglycosides (Kanamycin, Gentamicin, Amikacin and Neomycin) against bacterial strains of S. aureus and E. coli (Bento 2010). These results of the modulatory antibiotic activity demonstrated the synergistic potential of the Annonaceae family.

Natural products can present an antibacterial activity or resistancemodifying activity, due the presence of differences in polarity and secondary metabolites, which are related to affinities for biological action (Matias et al. 2010). As a result, they can demonstrate a greater interaction with the lipid bilayer of the cell membrane, affecting the respiratory chain and production of energy (Nicolson et al. 1999), or even make the cell more permeable to antibiotics, leading to the interruption of vital cellular activity (Burt 2004; Juven et al. 1994). These mechanisms of action can be due to the combination of antibiotic with extracts and fractions at a subinhibitory concentration added directly to the culture medium Coutinho et al. (2009).

This strategy is called "herbal shotgun" or "synergistic multieffect targeting" and refers to the utilization of plants and drugs in combination, 
affecting several targets at once and acting in a synergistic or antagonistic way. This procedure is not only through the combinations of extracts, but also due to combinations between natural products or extracts and synthetic products or antibiotics (Wagner and Ulrich-Merzenich 2009).

The results of this work demonstrated that $A$. squamosa (Annonaceae) must be studied more deeply about the possible usage as an adjuvant to the antibiotic therapy as a manner to combat the bacterial resistance to antibiotic. However, more assays are necessary to investigate this activity using in vivo models.

\section{References}

Amador MCV, Rodríguez FM, Rodríguez ZM, Guerra MJM, Barreiro ML (2006) Tamizaje fitoquímico, actividad antiinflamatória y toxicidad aguda de extractos de hojas de Annona squamosa L. Revista Cubana de Plantas Medicinales 11: 1-12.

Bento EB (2010) Bioprospecção farmacológica de plantas medicinais cultivadas no nordeste do Brasil: avaliação do efeito citoprotetor e antimicrobiano da Annona muricata Linnaeus. (graviola). Dissertação de mestrado - Universidade Regional Cariri- URCA, Crato, Brasil.

Brito HO, Noronha EP, França LM, Brito LMO, Prado MSA (2008) Análise da composição fitoquimica do extrato etanólico das folhas da Annona squamosa (ATA). Revista Brasileira de Farmacognosia 89: 180-184.

Burt S (2004) Essential oils: their antibacterial properties and potential applications in foods-a review. International Journal of Food Microbiology 94: 223-253.

Coutinho HDM, Costa JGM, Lima EO, Falcão-Silva VS, Siqueira-Júnior, JP (2008) Enhancement of the antibiotic activity against a multiresistant Escherichia coli by Mentha arvensis L. and chlorpromazine. Chemotherapy 54: 328-330.

Coutinho HDM, Costa JGM, Lima EO, Falcão- Silva VS, Siqueira JP (2009) In vitro interference of Hyptis martiusii Benth. \& chlorpromazine against an aminoglycoside-resistant Escherichia coli. Indian Journal of Medical Research 129: 566-568.

Cushnie TPT, Lamb AJ (2005) Detection of galangin-induced cytoplasmic membrane damage in Staphylococcus aureus by measuring potassium loss. Journal of Ethnopharmacology 101: 243-248.

Daferera DJ, Ziogas BN, Polissiou MG (2003) The effectiveness of plant essential oils on the growth of Botrytis cinerea, Fusarium sp. and Clavibacter michiganensis subsp. michiganensis. Crop Protection 22: 39-44.

Helander IM, Alakomi HL, Latva-Kala K, Sandholm TM, Pol I, Smid EJ, Gorris LGM (1998) Characterization of the action of selected essential oil components on Gram-negative bacteria. Journal of Agriculture and Food Chemistry 46: 3590-3595.

Javadpour MM, Juban MM, Lo WC, Bishop SM, Alberty JB, Cowell SM, Becker CL, Mclaughlin ML (1996) De novo antimicrobial peptides with low mammalian cell toxicity. Journal of Medicinal Chemistry 39: 107-3113. 
Juven BJ, Kanner J, Schved F, Weisslowicz H (1994) Factors that interact with the antibacterial action of thyme essential oil and its active constituents. Journal of Applied Bacteriology 76: 626-631.

Kotkar HM, Mendki PS, Sadan SVGS, Jha SR, Upasani SM, Maheshwari VL (2001) Antimicrobial and Pesticidal activity of partially purified flavonoids of Annona squamosa. Pest Management Science 58: 33-37.

Lima MRF, Ximenes CPA, Luna JS, Sant'Ana AEG (2006) The antibiotic activity of some Brazilian medicinal plants. Revista Brasileira de Farmacognosia 16: 300-306.

Matias EFF, Santos KKA, Almeida TS, Costa JGM, Coutinho HDM ( 2010) Atividade antibacteriana In vitro de Croton campestri A., Ocimum gratissimum L. e Cordia verbenaceae DC. Revista Brasileira de Biociências 8: 294-298.

Matias EFF, Santos KKA, Almeida TS, Costa JGM, Coutinho HDM (2011) Phytochemical prospection and modulation of aminoglycoside antibiotic activity by Croton campestris. Chemotherapy 57: 305-309.

Matos FJA (1997) Introdução à Fitoquímica Experimental. 2. ed. Fortaleza, Editora UFC, Fortaleza, Brasil.

Michelin DC, Moreschi PE, Lima AC, Nascimento GGF, Paganelli MO, Chaud MV (2005) Avaliação da atividade antimicrobiana de extratos vegetais. Revista Brasileira de Farmacognosia 15: 316-320.

Moellering Jr RC (2000) Novos desafios no campo das doenças infecciosas. In: Patógenos emergentes nas doenças infecciosas: Relatório Especial Hospital Práctice .Euroméd. Ed. Médicas, Barcelona, Espanha.

NCCLS (2003) Performance Standards for Antimicrobial Disk Susceptibility Tests; Approved Standard-Eighth Edition. NCCLS document M2-A8. Wayne, Pennsylvania, USA.

Nicolson K, Evans G, O'Toole PW (1999) Potentiation of methicillin activity against methicillin-resistant Staphylococcus aureus by diterpenes. FEMS Microbiology Letters 179: 233-239.

Robineau L (1995) Hacia una Farmacopea Caribeña. Editorial BUHO, Santo Domingo, República Dominicana.

Roig JT (1988) Plantas Medicinales, Aromáticas y Venenosas de Cuba. 2da ed. La Habana, Editorial Científico-Técnica, Habana, Cuba.

Santos SC, Mello JCP (2004) Taninos. In: Farmacognosia: Da Planta ao Medicamento. Simões CMO, Schenkel EP, Gosmann G, Mello JCP, Mentz LA, Petrovick PR. Eds. Editora da UFRGS/Editora da UFSC, Porto Alegre, Brazil, pp. 527-554.

Shirwaikar A, Rajendran K, Dinesh KC, Bodia R (2004) Antidiabetic activity of aqueous leaf extract of Annona squamosa in streptozotocin nicotinamide type 2 diabetic rats. Journal of Ethnopharmacology 91: $171-175$.

Souza VC, Lorenzi H (2008) Botânica Sistemática: guia ilustrado para identificação das famílias de Fanerógamas nativas e exóticas no Brasil, baseado em APG II. $2^{a}$ Ed. Plantarum, Nova Odessa, Brasil.

Vohora SB, Kumar I, Naqvi SAH (1975) Phytochemical, pharmacological, antibacterial and antiovulatory studies on Annona squamosa. Planta Medica 28: 96-100. 
Wagner H, Ulrich-Merzenich G (2009) Synergy research: approaching a new generation of phytopharmaceuticals. Phytomedicine 16: 97-110.

Womg KC, Khoo KH (1993) Volatile components of Malaysian Annona fruits. Flavour and Fragrance Journal 8: 5-10.

Zayachkivska OS, Konturek SJ, Drozdowicz D, Konturek PC, Brzozowsk T, Gzhegotsky MR (2005) Gatroprotective effects of flavonoids in plants extracts. Journal of Phisiology and Pharmacology 56: 219-231. 